\title{
POST-CONFLICT DECENTRALIZATION: DYNAMICS OF LAND AND POWER IN UNITY STATE - SOUTH SUDAN
}

\author{
Sara de Simone ${ }^{1}$ \\ University of Naples L'Orientale
}

\begin{abstract}
:
Decentralized state-building in post-conflict settings is believed to bring about a number of positive outcomes that range from increased government accountability and local participation, to internal stability thanks to higher opportunity of political engagement. South Sudan is currently undertaking a decentralization process supported by international organizations through the institutionalization of the local administration system shaped during the war in SPLM controlled areas. Through the analysis of Unity State case study, this article shows how, despite being at a very initial phase, local government reforms in South Sudan are producing new localized disputes over access to resources that articulate themselves as border disputes. These disputes ultimately revolve around the access to resources, but also keep a tribal characteristic due to the overlapping of customary and administrative domains that entrenches local perceptions of access to land and services being granted based on tribal affiliation.
\end{abstract}

Keywords: South Sudan, Decentralization, Internal Borders, Resources Access.

\section{Resumen:}

Se cree que la construcción estatal descentralizada en escenarios post-conflicto trae consigo, gracias a la mayor oportunidad de participación política, una serie de resultados positivos que van desde un aumento de los mecanismos gubernamentales de rendición de cuentas y de la participación local hasta la estabilidad interna. Sudán del Sur está llevando a cabo actualmente, con el apoyo de organizaciones internacionales, un proceso de descentralización a través de la institucionalización del sistema de administración local configurado durante la guerra en las zonas controladas por el MLPS. Mediante el análisis del Estado de Unidad como estudio de caso este artículo muestra cómo, a pesar de estar en una fase muy inicial, las reformas del gobierno local en Sudán del Sur están produciendo nuevos conflictos localizados por el acceso a los recursos que se articulan como disputas fronterizas. Estas disputas giran en última instancia en torno al acceso a los recursos, pero también mantienen características tribales debido a la superposición de los ámbitos consuetudinarios y administrativos, lo cual afianza la percepción local de que el acceso a la tierra y a los servicios se otorga en función de la afiliación tribal.

Palabras clave: Sudán del Sur, descentralización, fronteras interiores, acceso a los recursos.

\section{Copyright $(9)$ UNISCI, 2013.}

Las opiniones expresadas en estos artículos son propias de sus autores, y no reflejan necesariamente la opinión de UNISCI. The views expressed in these articles are those of the authors, and do not necessarily reflect the views of UNISCI

\footnotetext{
${ }^{1}$ Sara de Simone is a PhD candidate in African Studies at University of Naples L'Orientale, Department of Asia, Africa and Mediterranean. She holds a Master Degree in Development Studies and started to work on local conflict management in South Sudan in 2010. Her main research areas are: local governance, decentralization, local conflict management. She can be reached at sara.desimone@gmail.com. Department of Asia, Africa e Mediterranean, University of Naples L'Orientale, Palazzo Corigliano, Piazza S. Domenico Maggiore $12,5^{\text {th }}$ floor -80134 Napoli.
} 


\section{Introduction}

After the end of the Cold War, peace-building has increasingly been understood as a "multifaceted" liberal project, whose aim is not only to promote a "negative peace", ${ }^{2}$ but also to address root causes of conflicts seen as stemming from poverty, underdevelopment and the states' lack of capacity of keeping security under control. ${ }^{3}$ This convergence of the peace, security and development agendas ${ }^{4}$ gained even more strength after 11/09/2001, with US pivotal role in emphasizing the importance of democracy and good governance.

Literature on state failure usually assumes that a functioning state should be able to monopolize the means of violence, control its territory and population, keep diplomatic relations with other states, deliver services to its citizens and promote economic growth. ${ }^{5}$ However, critical literature opposing what is considered to be an ethnocentric top-down approach to statehood in the developing world has emerged both in the domain of Peace Studies, with a wide number of contributions on the "local" agency and hybridization processes, ${ }^{6}$ and in African Studies, where many scholars have claimed that this perspective fails to capture real local dynamics of organization in African States and societies whose outcome can sometimes seem at odds with western standards. ${ }^{7}$ This notwithstanding, the policy-making domain is still widely dominated by a technical approach to state-building, focusing on institution-building.

During the '90s and early 2000s, increasing awareness of the failures of central government institution-building pushed international actors to reformulate the discourse on state-building through the democracy - good governance lens. Democratic decentralization, in opposition to deconcentration brought about by structural adjustment programs (SAPs) in the 80 s, gained prominence as a tool for promoting effective local governance, development and peace. ${ }^{8}$ Notwithstanding international discourses on local participation and ownership, as well as on the importance of context-specific approaches, the focus remains on local institutionbuilding and legal frameworks ${ }^{9}$, again often failing to consider the socio-political realities on

\footnotetext{
${ }^{2}$ Negative peace is generally understood as "absence of collective violence". For an analysis of negative and positive forms of peace see Galtung, Johan (1967): Theories of Peace: A Synthetic Approach to Peace Thinking, unpublished, p.12, available at

http://www.transcend.org/files/Galtung_Book_unpub_Theories_of_Peace -

A Synthetic_Approach to Peace Thinking 1967.pdf.

3 Newman, Edward; Paris, Roland; Richmond, Oliver P. (eds.) (2009): New Perspectives on Liberal Peacebuilding, Tokyo/New York, United Nations University Press.

${ }^{4}$ Duffield, Mark (2001): Global Governance and the new Wars: The Merging of Development and Security, London/New York, Zed Books.

${ }^{5}$ Helman, Gerald B. and Ratner, Steven R.: "Saving Failed States", Foreign Policy, no89 (December 1992), pp. 3-20; Rotberg, Robert I.: "Failed States, Collapsed States, Weak States: Causes and Indicators" in Rotberg, Robert I. (ed.) (2003): State Failure and State Weakness in a Time of Terror, Washington D.C., Brookings Institution Press; Eizenstat, Stuart E.; Porter, John E. and Weinstein, Jeremy M.: "Rebuilding Weak States", Foreign Affairs, vol. 84, nº1 (January 2005), pp. 134-147.

${ }^{6}$ Richmond, Oliver P. (2011): A Post-Liberal Peace, Oxon/New York, Routledge; Newman E. et al., op. cit.

${ }^{7}$ Bayart, Jean-François: "L'historicité de l'Etat importé", Les Cahiers du CERI, nº15 (1996), available at http://www.sciencespo.fr/ceri/sites/sciencespo.fr.ceri/files/cahier15.pdf; Chabal, Patrick and Daloz, Jean-Pascal (1999): Africa Works: Disorder as a Political Instrument, Oxford, James Currey.

${ }^{8}$ Olowu, Dele and Wunsch, James S. (eds.) (2004): Local Governance in Africa: The Challenges of Democratic Decentralization, Boulder, Lynne Rienner.

9 UNDP: "Decentralised Governance for Development: A Combined Practice Note on Decentralisation, Local Governance and Urban/Rural Development" (April 2004), available at

http://www.undp.org/content/dam/aplaws/publication/en/publications/democratic-governance/dg-publicationsfor-website/decentralised-governance-for-development-a-combined-practice-note-on-decentralisation-localgovernance-and-urban-rural-development/DLGUD_PN_English.pdf;USAID: "Democratic Decentralization
} 
the ground, the modes of interaction between political elites and their constituencies and the areas of tension that may (and almost surely do) exist in post-conflict contexts.

South Sudan has entered the post-conflict phase with the signing of the Comprehensive Peace Agreement in 2005 after a decade long peace process strongly supported by the international community. International partners still have a huge presence and an important role in supporting the country's peace-building and state-building effort in a number of sectors that range from security sector reform to the rule of law and from fiscal arrangements to local government empowerment.

This paper will show that a form of decentralized state-building in a context where formal state structures at a local level did not previously exist needs to start from the delimitation of territorial units. The specific history of an area, together with legal provisions shaping the process of decentralizing power, contribute to the local understanding of what being or not being included in a certain local government unit means. This specific case will show how border disputes arising between counties in the northern part of Unity State mainly revolve around access to land and services, grounding its roots in the history of tribal identity manipulation and the perception of access to resources only being granted on tribal lines. ${ }^{10}$

This paper relies on two months field research mainly in Unity State and, secondly, in Juba, between January and March 2013. South Sudan is extremely diverse in terms of local political "traditional" institutions, livelihood strategies, culture, environmental conditions, etc., therefore it would be hasty to extend findings from one specific area to all the others because they would necessarily be biased by a partial view only. The arguments made in this paper are therefore refer mainly to Unity State, unless differently specified.

\section{Decentralized State-Building}

In 2000s, all major international aid agencies started to produce policy papers, working notes, handbooks on decentralization and local governance, and on the expectations connected with its implementation in developing and post-conflict countries. ${ }^{11}$ In her paper "Decentralization Hybridized", Annina Aeberli analyzes different understandings emerging from this wide policy-oriented literature taking UNDP, the World Bank, USAID and GIZ ad examples. ${ }^{12}$ She notes that all of them accept Rondinelli's distinction between political, administrative and fiscal decentralization, and all of them put on it ambitious expectations that can be summarized in four points:

Programming Handbook", (June 2009), available at http://webcache.googleusercontent.com/search?q=cache:QctFWeHuqgJ:capacity4dev.ec.europa.eu/system/files/file/19/07/2011 _ 0957/8usaid_decentralisation_programming handbook.pdf $+\& \mathrm{~cd}=2 \& \mathrm{hl}=\mathrm{it} \& \mathrm{ct}=\mathrm{clnk} \& \mathrm{gl}=\mathrm{it}$.

${ }^{10}$ In this paper, I will often use the word tribe -tribalism, tribal identity- to identify groups that constitute sociopolitical entities sharing a common identity, language and customs. I am using this word because all of my interviewees did whenever speaking of South Sudan politics.

${ }^{11}$ UNDP: “Decentralised Governance ...", op. cit.; USAID: “Democratic Decentralization...” op. cit.; EuropAid (2007): Supporting Decentralisation and Local Governance in Third Countries, Tools and Methods Series, Reference Document ${ }^{\circ} 2$, Brussels, European Commission, available at http://ec.europa.eu/europeaid/what/governance/documents/decentralisation_local_governance refdoc final en.p $\frac{\mathrm{df}}{12}$

$\frac{\mathrm{df}}{12}$ Aeberli, Annina: "Decentralisation Hybridized: A Western Concept on its Way through South Sudan", ePapers The Graduate Institute, $\mathrm{n}^{\circ} 14$ (July 2012), Geneva, The Graduate Institute of International and Development Studies. 
1) Strengthening democracy, through an increased participation of minorities and vulnerable groups.

2) Efficiency and transparency, thanks to the reduced distance between governments and citizens that increases governments' accountability and pushes them to be more effective.

3) Economic development, through the local governments redistributive role and the capacity of mobilizing local resources.

4) Internal peace and stability, promoting local dialogue and control over public programs, and increasing state visibility and legitimacy at the local level.

These governance, economic and security improvements are expected to come as a consequence of well-designed institution-building or reform with a focus on technical arrangements more than on political processes underlying local governments functioning.

In the arena of conflict management and peace-building, decentralization can be considered a tool for addressing "latent conflict at national level"13 through opening a broader political space for inclusion of groups previously excluded from the management of power and granting greater autonomy to each group. Crawford and Hartman show that in a number of African post-conflict settings, decentralization has indeed been chosen as a system of government. ${ }^{14}$ However, Schlenberger's contribution to their book also highlights the risks linked with a particular design of decentralization policies of increasing conflict at the local level, reminding us that the actual impact of decentralization reforms is far from being straight-forward. ${ }^{15}$

South Sudan, as a newborn country that formally came out of the war less than 10 years ago, is considered to be in dire need of all the four elements and therefore the international thrust towards a decentralized state-building is quite strong. UNDP, the World Bank, GIZ, USAID are implementing programs in partnership with local governments or aimed at strengthening the decentralization process through reinforcing central coordinating institutions. For example, the UNDP has a "Support to Decentralization Program" under its Democratic Governance Program, which is implemented in partnership with the Local Government Board and aimed at increasing its planning and budgeting as well as coordination capacities. $^{16}$ An example of projects implemented directly in partnership with local governments is the World Bank Local Governance and Service Delivery Project, which includes grants delivery to Counties for Payam development ${ }^{17}$, and the Local Government

\footnotetext{
${ }^{13}$ Crawford, Gordon and Hartman, Christof (eds.) (2008): Decentralization in Africa: a Pathway out of Poverty and Conflict?, Amsterdam, Amsterdam University Press, p. 245.

${ }^{14}$ Ibid.

${ }^{15}$ Schelnberger, Anna Katharina: "Decentralization and Conflict in Kibaale, Uganda", in Crawford, G. and Hartman, C. (eds.) (2008): Decentralization in Africa: a Pathway out of Poverty and Conflict?, Amsterdam, Amsterdam University Press, pp. 169 - 190.

${ }^{16}$ Interview with UNDP Project Specialist of Democratic Governance Program. The project has a length of 2 years and a total cost of 353.000\$. For further information, see UNDP website: http://www.ss.undp.org/content/south_sudan/en/home/operations/projects/democratic_governance.html

${ }^{17}$ Interview with Under-Secretary General of the Local Government Board. The project has a length of 5 years and the Bank committed \$98,50 million for its implementation. For further information, see the World Bank website:

http://www.worldbank.org/projects/P127079/local-governance-service-delivery-program?lang=en
} 
Fund created by USAID through the BRIDGE program for implementing small projects requested by Counties and community groups. ${ }^{18}$

Besides this external thrust to decentralization, there is also internal inclination towards such a form of governance, usually justified with the incredibly diverse socio-political landscape characterizing the country. Due to its particular history of internal ethnic divisions, the ruling party has always declared great commitment for the devolution of power to local levels of government, in order to safeguard the right to self-rule of each and every community in South Sudan. Even before the peace agreement was signed and the Government of Southern Sudan formed, in 2000 the SPLM released the document "Peace through Development in the Sudan" in which the relevance of the decentralized civil administration was directly linked with promoting peace and ensuring social and economic development through service delivery, democracy and human rights protection. This discourse was reaffirmed even more strongly after 2005, and the way in which it is being applied into practice will be looked at in the following pages.

\section{South Sudan Post-conflict Local Government}

\subsection{The Current Legal Framework and its Implementation}

The current system of local government in South Sudan results from a process of formulation that lasted some years, and its decentralized nature was stated in the Power-sharing Protocol of the Comprehensive Peace Agreement. ${ }^{19}$ Although the latter did not officially foresee southern independence and was not specific on the local government structure, the Interim Constitution of Southern Sudan (ICSS) ${ }^{20}$ instituted the current administrative units drawing from previous experiences of local government.

In 2003, a team made of SPLM, UNDP and GIZ representatives started to work on the Local Government Framework, which was completed in 2006. The Local Government Framework (LGF) encloses SPLM commitment to a decentralized form of government, which is believed to better fit with the country's diversity and the people's struggle for self-rule:

"Throughout the struggle for liberation and self rule of the people of Southern Sudan, the SPLM/A as the leader of the struggle was always committed to decentralization and local government as the most empowering and democratic tool of self-rule, as evidenced by their vision and mission. It also enshrined local government into the Interim Constitution of Southern Sudan". ${ }^{21}$

\footnotetext{
${ }^{18}$ Interview with the Project Officer of Governance Sector in Bentiu, March 2013. See Winrock website: https://www.winrock.org/fact/facts.asp?CC $=5998 \& \mathrm{bu}=$. Winrock is one of USAID implementing partners.

${ }^{19}$ The Comprehensive Peace Agreement - Protocol on Power-sharing, Part I, 1.5.1.1

${ }^{20}$ The ICSS was in force between 2005 and 2011 and was replaced by the Transitional Constitution of the Republic of South Sudan (TCRSS) after independence, but no major changes in local government structures are foreseen. On the other hand, there is perhaps a slight change in the political will of devolving power, as the new constitution increases the powers of the national President at the expenses of States' executive and legislative organs giving him the power to remove state governors and dissolve state legislative assemblies. Transitional Constitution of the Republic of South Sudan, 2011, art. 101.

${ }^{21}$ Local Government Framework, 2006, 2.2.3, p. 30.
} 
The SPLM vision of decentralization is stated in the same document, and it is based on Garang's principle "Self-rule for the people of Southern Sudan, by taking towns to the people", through "The establishment of decentralized, democratic, efficient, effective, accountable and gender sensitive Local Government". ${ }^{22}$ As a follow-up of the LGF, the Local Government Act was approved in 2009.

According to this legal framework, the Republic of South Sudan is divided into ten states, each with a legislative assembly, a High Court and an executive power led by a governor and its ministries. In each state, the system of local government is so structured:

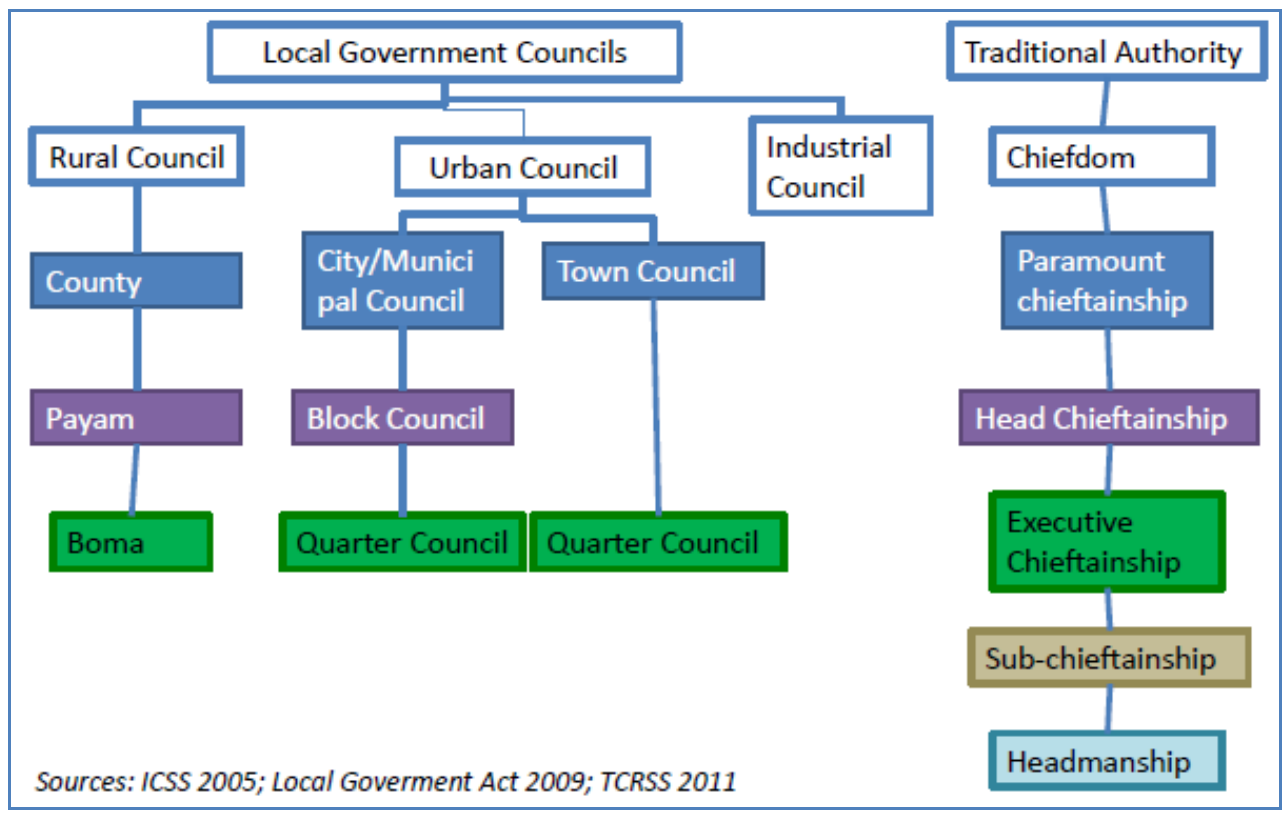

The Local Government Act foresees three different types of local government councils: urban, rural and industrial. Nevertheless, rural councils constitute the great majority: there are no industrial councils at the moment, and only a few urban councils are starting to be established beside the capital town. ${ }^{23}$

The County is the highest level of local government, not only exercising deconcentrated powers but also being accountable to its citizens thanks to the elective nature of its legislative council members and of the County Commissioner. Payam and Boma levels have an administrative role, with the Boma being the most important domain of traditional authorities. The role of traditional authorities is in fact mainly judiciary, managing traditional courts and resolving local conflicts through customary practices. According to the Local Government

\footnotetext{
${ }^{22}$ Ibid., p. 30.

23 According to Aeberli's observation in Central Equatoria (2012), despite being theoretically at the same hierarchical level as counties, Town (urban) Councils are being considered subjected to the latter's authority. My personal observation in Unity State is quite different, though: Bentiu has apparently not yet gained a Town Council status (although some stated differently and institutions such as Block leaders already exist), but the reason why governmental officials and officers to which I spoke wanted the town status to change was to subtract it from Rubkhona County authority (under which it currently lays) in order to avoid it being involved in the tribal dynamics linked to the administration of the rural areas. Aeberli A., op. cit.
} 
Act, their election/selection has to follow traditional methods that vary from one place to another. $^{24}$

The implementation of these provisions is at a very early stage and there are reasons to argue that local governance still varies greatly across the country. ${ }^{25}$ Generally speaking, however, some aspects of the decentralization reform are still far from being implemented. In most cases, county legislative assemblies do not exist, and County Commissioners are still predominantly appointed by state governors. Borders of local government councils and administrative units have yet to be officially demarcated, and how they are supposed to raise the necessary resources for their functioning is still unclear due to their weak fiscal basis, scarce central and state government grants and the general dependence on aid funds for service delivery. The role of traditional authorities has to be further clarified, although their empowerment is still strongly required by the local population. ${ }^{26}$ As judges in traditional courts, they are often criticized for taking over criminal cases that go beyond their official competences due to the difficulties of accessing the statutory judiciary especially from the rural areas. ${ }^{27}$ They are looked at as the main peace-keepers in their communities, and considered as community representatives in a number of issues -for example, in negotiating development projects in a particular locality. In most of the cases, chiefs are elected, but especially for those at lower levels, it is rather unclear how the election works: who is entitled to vote, how candidates are selected. It is reasonable to argue that representation of weaker social groups such as women, youth and migrants is not guaranteed. ${ }^{28}$

\subsection{Origins of the Current Structure}

The complex structure outlined above, as well as the territorial extension of the politicoadministrative units, are the cumulative product of decades of formal and de facto local governance structures.

During the colonial rule, the region was divided into three provinces: Bahr el Ghazal, Upper Nile and Equatoria. Each province was headed by a British commissioner and indirect rule was exercised by local chiefs, that in many cases were created by the colonial rule to govern segmented and acephalous societies. ${ }^{29}$ This division into three provinces and many local chiefdom was maintained until Nimeiri took power and then re-established with the SPLM/A civil administration structure. ${ }^{30}$ Despite having been dropped after the signing of the

\footnotetext{
${ }^{24}$ Government of Southern Sudan (2009): Local Government Act, Ch. XII Section 117.

${ }^{25}$ Hoehne, Marcus (2008): Traditional Authorities and Local Government in Southern Sudan, Washington D.C., World Bank; Aeberli, op. cit.; direct observation in Unity State between January and March 2013.

${ }^{26}$ Ibid.

${ }^{27}$ Leonardi, Cherry; Moro, Leben Nelson; Santschi, Martina; Isser, Deborah H. (2010): Local Justice in Southern Sudan, Washington, D.C., United States Institute of Peace; interviews with Chiefs of the Traditional Town Court in Bentiu, February 2013.

${ }^{28}$ Interviews with Rubkhona County Commissioner, Nyeel Payam acting administrator, civil society members in Unity State, February-March 2013.

${ }^{29}$ Some exceptions of more centralized societal organization such as those of Shilluk and Azande must be mentioned.

${ }^{30}$ SPLM (2000): Peace through Development in the Sudan, available at http://www.splmtoday.com/index.php/peace-through-dev-splm-33.
} 
CPA with the recognition of the ten States as "regional" governments, ${ }^{31}$ it still partly shapes the people's identity. ${ }^{32}$

In the early 70s, Nimeiri tried to abolish local traditional authorities without achieving any significant result. With the Addis Abeba Agreement in 1972 ending the civil war between the government and the rebel movement Anyanya I, Southern Sudan was unified under a regional government that was perceived to be Dinka-dominated by Southern Sudanese nonDinka population, particularly from the Equatoria region. Between the end of the '70s and the beginning of the '80s, a group of southern politicians mainly from Equatoria started to advocate further decentralization for the South, restoring the three regions and showing deep cleavages among the southern leadership. In 1983 Nimeiri accepted this request, dissolving the southern regional government and causing the failure of the Addis Abeba Agreement. This process is known as "kokora", and it has a negative connotation for most of Dinka and Nuer people. ${ }^{33}$

According to Douglas H. Johnson ${ }^{34}$ the central government in Khartoum was in fact never able to effectively control southern territory, under neither colonial rule nor successive regimes. Therefore, for a long time, the only authorities recognized by the local people were traditional chiefs who, although often being central government local extensions, enjoyed great legitimacy in the eyes of the population and exercised judicial and, to some extent, executive powers. Despite Nimeiri's aforementioned efforts to change the local government structure with the institution of a three levels bureaucratic government, the actual position of local traditional authorities remained relatively unchanged ${ }^{35}$ until the beginning of the war in 1983, when the SPLA started imposing its military authority in the liberated areas. ${ }^{36}$ Even then, the existence of an administrative structure in SPLM/A controlled areas before 1994 is questioned. ${ }^{37}$ Despite slight differences in timing and degree, however, there is general agreement around the idea that the second Sudanese civil war has affected the local governance system more than anything else before.

\footnotetext{
${ }^{31}$ States were introduced in 1994 with the $11^{\text {th }}$ Constitutional Decree of the Government of Sudan led by the National Islamic Front.

${ }^{32}$ See for example the regional conferences that have been recently held in the first quarter of 2013 formulating demands for more effective decentralization [Sudan Tribune: "Greater Bahr el Ghazal calls for conference to discuss country situation", 12 May 2013, available at http://sudantribune.com/spip.php?article46552]; and the debate around their positive or negative impact on nation-building [Deng Biong, Justice: "A call to discourage Regional Conferences in South Sudan", Sudan Tribune, 1 June 2013; Deng, Lual A.: "Regional Conferences in South Sudan are Imperative", Weekly Review - The Sudd Institute, (25 June 2013)].

${ }^{33}$ Branch, Adam and Mampilly, Zachariah C.: "Winning the War, but Losing the Peace? The Dilemmas of SPLM/A Civil Administration and the Tasks Ahead", Journal of Modern African Studies, vol. 43, n¹ (2005), pp. 1-20; Aeberli, op. cit.

34 Johnson, Douglas H.: “The Sudan People's Liberation Army and the Problem of factionalism”, in Clapham, Christopher (ed.) (1998): African Guerrillas, Oxford, James Currey; Johnson, Douglas H. (2003): The Root Causes of Sudan's Civil War, Bloomington, Indiana University Press.

${ }^{35}$ The Native Administration Act (1970) abolished native authorities. The People's Local Government Act (1971) created a bureaucratic government system with a central government, provincial councils led by appointed provincial commissioners, and elected local councils (including districts, towns, rural areas, villages and nomadic groups). According to Rondinelli, these reforms led to an exponential increase in the number of local administrative units (from 86 to 5000) with no significant transfer of power nor resources to the local level. Rondinelli, Dennis A.: “Administrative Decentralisation and Economic Development: the Sudan's Experiment with Devolution", The Journal of Modern African Studies, vol. 19, issue 4 (December 1981), pp. 595-624.

${ }^{36}$ Johnson D. H. "The Sudan People's Liberation Army...", op. cit.; Johnson D. H., "The root causes...", op. cit.

${ }^{37}$ African Rights (1997): Food and Power in Sudan: A Critique of Humanitarianism, London, African Rights, available at

http://beta.justiceafrica.com/publications/online-books/food-and-power-in-sudan-a-critique-of-humanitarianism/
} 
Compared to previous south Sudanese rebel movements, SPLM/A declared more ambitious objectives and, during the civil war that started in 1983, was able to capture and control wide territories. Øystein $\mathrm{H}$. Rolandsen traces a very detailed history of the administrative structures' evolution in SPLA controlled areas, analyzing not only the movement's documents from the early ' 90 s, but also the two main corpus of studies available on the matter, those from the British scholar Douglas H. Johnson and from the UK based advocacy group African Rights. These have different positions concerning the existence of some form of local administration in the early stages of the war. Johnson maintains that a form of local administration did exist from the very beginning, headed by the Civil/Military Administration, appointed by the Zonal Commander and relying on traditional authorities, taking as evidence the ability to keep raiding and local disputes under control through traditional mechanisms. It is however questioned what was the official position of the SPLA towards traditional authorities: while some say that the movement always recognized their legitimate role since the beginning of the war, ${ }^{38}$ some others maintain that, due to its initial socialist vision, traditional authorities were opposed and considered retrograde institutions. ${ }^{39}$ In any case, they played an important role in the control of the territory, and their judicial and executive powers were officially recognized with the creation of the Civil Administration of the New Sudan (CANS) in 1996.

The process that led to the creation of a civil administration started in 1991, following two major events that determined both an external and internal thrust on the rebel movement: the fall of Mengistu in Ethiopia, and the breakaway of the Nasir faction from the SPLA led by former senior SPLA commanders. The Ethiopian regime had been for a long time SPLA major ally, providing it with weapons, supplies and support in training. SPLA headquarters and training camps were located across the Ethiopian border. With Mengistu's fall, the new regime withdrew its support and the SPLA found itself in need of new sources of supply that were identified in the relief aid brought in the country by Operation Lifeline Sudan. ${ }^{40}$ At the same time, a few months later, three senior commanders from the Upper Nile region broke away from the rebel movement and created the SPLM/A Nasir, whose name, composition and allegiance changed many times in the following ten years. The rebel commanders accused the SPLA leader John Garang of undemocratic, exclusive and militaristic rule, and presented themselves as a democratization force which granted them some attention by the international community. The increasingly competitive environment in terms of popularity and access to resources in which the SPLA found itself pushed it to undertake a process of internal reform in order to demonstrate its will to improve its governance system. ${ }^{41}$

By the end of 1991, a meeting of the SPLA Political Military High Command (PMHC) introduced the division of the southern territory in County, Payam and Boma in all SPLA controlled areas, although the decision was not implemented until a few years later.

\footnotetext{
38 Soux, Susan: "Southern Sudan: Local government in complex environments. Project Assessment", The DGTTF Series, UNDP (2010), p. 15, available at

http://www.undp.org/content/dam/aplaws/publication/en/publications/democratic-governance/dgttf-/southernsudan-mainstreaming-gender-empowerment-in-local-government---an-assessment/DGTTF\%20SSudan.pdf.

${ }^{39}$ World Bank: "Sudan: Strengthening Good Governance for Development Outcomes in Southern Sudan. Issues and Options", Public Sector Reform and Capacity Building Unit, Africa Region (April 2010), p. 24; Hoehne, op. cit.

${ }^{40}$ Operation Lifeline Sudan was the first and probably biggest humanitarian action coordinated by UNICEF, involving a number of international NGOs and UN agencies. It started in 1989 and continued throughout the '90, despite huge criticism against its incapability of avoiding being co-opted in the highly politicized local context. For a comprehensive analysis of OLS and its shortcomings, see African Rights, op. cit.

${ }^{41}$ Rolandsen, Øystein H. (2005): Guerrilla Government: Political Changes in the Southern Sudan during the 1990s, Oslo, Nordiska Afrikainstitutet; Johnson D. H.: "The root causes...", op. cit.
} 
The SPLM National Convention held in 1994 at Chukudum created a real government structure for the liberated areas, with a central executive and legislative power held respectively by the National Executive Council and the National Liberation Council. The judiciary was also reformed, with the formalization of three levels of traditional courts (A at Boma level, B at Payam level, C at County level) and a parallel system of military courts. On one side, the authority of traditional chiefs was recognized, on the other it was subjected to the military, ${ }^{42}$ which, according to some, negatively affected their legitimacy and capacity of exercising their conflict management role in the eyes of the population. ${ }^{43}$ After the National Convention, 49 local councils (i.e. Counties) were created, but their number doubled in the following years through presidential decrees in response to the local population demands of self-administration, so that in 2005 the Counties were $98 .{ }^{44}$ According to Johnson, the number of local chiefs (and chiefdoms) also increased due to the recognition of new tribal section and sub-section by County Commissioners, in order to have a higher number of positions to distribute to their local clienteles. ${ }^{45}$

At Boma and Payam levels appointed SPLA administrators were the links with local traditional authorities, whose main responsibility was to keep local insecurity under control. The County was led by an appointed County Commissioner drawn from SPLA ranks, and was the level responsible not only for raising taxes but also for delivering services through County Development Committees created in 1999, that should have taken over some of the service delivery and aid coordination activities run by the Sudan Relief and Rehabilitation Association since $1989 .^{46}$

Evidence of how much these administrative reforms were actually implemented is limited and varies across the territory. Nevertheless, the SPLA was able to create a governing structure parallel to the customary one, recognizing the latter but also subjecting it to civil authorities that in practice were never really separated from the military apparatus. Despite being weakened in terms of autonomy and legitimacy by the war, local traditional authorities are still regarded as the most significant institution in the people's daily lives, especially in the rural areas, and the bottom-up demands for their re-empowerment is strong according to one of the studies on the state of local government conducted during the formulation process of the Local Government Framework. The same study also highlighted the persisting supremacy of military rule over civil administration at County level and the proliferation of counties into tribal constituencies. ${ }^{47}$

\section{Why Counties Matter}

This paper will now focus on the County level of government and on its role in the current settings. This choice is due to two reasons. First, the County is the first level of what is

\footnotetext{
${ }^{42}$ Ibid.

${ }^{43}$ Hoehne, op. cit.; Bradbury, Marc; Ryle, John; Medley, Michael and Sansculotte-Greenidge, Kwesi (2006): Local Peace Processes in Sudan: A Baseline Study, London/Nairobi, Rift Valley Institute; Hutchinson, Sharon E.: "A Curse from God? Political and Religious Dimensions of the Post 1991 Rise of Ethnic Violence in South Sudan", Journal of Modern African Studies, vol. 39, n² (June 2001), pp. 307-332.

${ }^{44}$ Local Government Framework, op. cit., section 1.4.4.

45 Johnson D. H.: “The Sudan People's Liberation Army...”, op. cit.

46 The SRRA was the humanitarian branch of the SPLA, in charge of channeling aid flows to the local population in SPLA controlled areas, but actually often used to divert aid according to the rebel movement interests and needs. Branch and Mampilly, op. cit.; Rolandsen, op. cit.

${ }^{47}$ Local Government Framework, op. cit., 2.3.3 $3^{\text {rd }}$ Framework.
} 
constitutionally defined as Local Government. Although states play a very important role in the decentralized system of governance South Sudan is currently implementing, and they also represent an interesting level of analysis of inter-communal violent conflicts that mostly occur in the form of cattle-raiding and see states' authorities actively involved in conflict-resolution efforts $^{48}$, states are not considered to be part of the local government structure, but above it. Their role and position in the governmental hierarchy and their representation at the national level through the Council of States ${ }^{49}$ seems to suggest a federal system, which is however never mentioned in the Transitional Constitution. The second reason for choosing the County as level of analysis is that the more the local government legal framework is produced and implemented, the more Counties are empowered and increase their importance in the management of local issues.

\subsection{Counties' Design and Functions}

When the local government structure was designed, the SPLM largely relied on assumingly pre-existing customary boundaries between tribes, sub-tribes, sections and sub-sections ${ }^{50}$ in order to trace borders between Counties, Payams and Bomas. Tribal "traditional" boundaries are nevertheless something hard to officialize, because it implies a snapshot of ethnic groups territorial distribution in a precise moment of history, which is even harder to achieve in a context that has been characterized by massive displacement for decades. In a paper on access to land and pastures in Southern Sudan commissioned by FAO in 2001, Paul De Wit suggests that, despite discourses on the endorsement of "pre-existing" "customary" boundaries, these were often manipulated with the aim of influencing population movements, ${ }^{51}$ and new narratives were produced. After the end of the war, local borders so created were more or less kept untouched and are still recognized as the borders of local government units, though not yet officially demarcated. According to a senior official in the Local Government Board, colonial maps of internal boundaries should be taken as a landmark in the process of demarcation as written evidence of traditional borders, but also acknowledges the lack of these maps. ${ }^{52}$

The Local Government Act (2009) clarifies both the structure and the duties of local government councils. Besides differentiating between Rural Council (County), Urban Council (Town and City) and Industrial Council, it outlines their internal structure which shall be composed of a legislative council made of 35 elected members with $25 \%$ women's representation, an executive council made of departments directors and secretaries headed by a County Commissioner/Mayor/Town Clerk elected directly by the population, and a customary law council as a judiciary organ. ${ }^{53}$

\footnotetext{
48 See for example: Gatdet Dak, James: "South Sudan steps up inter-state community reconciliation conferences", Sudan Tribune, 4 January 2009, available at http://www.sudantribune.com/spip.php?article29770; Radio Miraya: "Warrap Holds Interstate Peace Conference", 12 July 2013; Nonviolent Peaceforce: "Interstate Conflict in South Sudan: a Case Study in Unarmed civilian peacekeeping", 20 October 2011, available at http://www.nonviolentpeaceforce.org/interstate-conflict-south-sudan-case-study-unarmed-civilianpeacekeeping.

${ }^{49}$ The Council of States is made of former members of the Council of States of the Republic of Sudan plus 20 members appointed by the President. Transitional Constitution, op. cit., Part V, Ch. I, 58.

${ }^{50}$ Johnson D. H., "The Sudan People's Liberation Army..." op. cit.

${ }^{51}$ De Wit, Paul (2001): Legality and Legitimacy: A Study of the Access to Land, Pasture and Water, Rome, FAO. For example, the border of the Lou Nuer area was moved by the SPLA - North of the Sobat River to prevent Lou Nuer to move southwards in the territory of Dinka Bor.

52 Interviewed in Juba in January 2013.

${ }^{53}$ Local Government Act, op. cit., Section 22. As mentioned above, however, none of these provisions is currently implemented.
} 
According to the Local Government Framework, service delivery, public order and development are the three basic functions of the local government. Its guiding principle is summarized in its subtitle: "Taking towns to the people", which is generally considered as a synonym for bringing services to the rural areas. ${ }^{54}$ County competences and duties, under the States' supervision following the principle of subsidiarity, include, among others, the regulation and management of land and natural resources including land acquisition for development purposes, local revenues management and the power to sign agreement with private companies and donors for public service delivery. ${ }^{55}$

Being the highest level of the Local Government, County authorities are in a strategic position for whatever concerns local development and, as level of statutory government closest to the grassroots, they are often considered to represent the interests of the local population, ${ }^{56}$ despite their executives still being appointed by state governors.

\subsection{Financial Resources}

Local Government Council financial viability should rest on local tax collection, ${ }^{57}$ local revenues, and government and donor grants. ${ }^{58}$ Donor grants are expected to be the most important contribution to service delivery and development infrastructure, as it appears in the Rubkhona County strategic plan for 2013-2015. The County's expected expenses for the year 2013 amount to 112.600.000 SSP (decreasing to about 5.900.000 and 3.700.000 in the following years). Tax revenues are expected to be around 1.400.000 SSP in 2013 and 1.800 .000 in 2015, while state government grants are expected to be 3.400 .000 SSP per year on average. It seems that donors and relief agencies are expected to fill the 2013 huge gap. According to some of my governmental interviewees, ${ }^{59}$ state government grants are mostly aimed at paying county personnel salaries. While these top-down channels of financial resources are more or less functioning, the local capacity of tax collection appears to be very weak due to both weak fiscal basis in the absence of a strong private sector and widespread unofficial taxation that does not contribute to sustain the local government.

Since most of the financial resources are expected to come from above, the County is seen as an important interface to attract external funding to the community. This explains the proliferation of Counties and lower administrative units as it is described by Schomerus and Allen ${ }^{60}$ and recalled by Aeberli. ${ }^{61}$ Local claims for self-rule and access to resources go hand in hand with the opportunity of enlarging clients' networks for those that appoint

\footnotetext{
${ }^{54}$ Interviews to SPLM acting chairman in Unity State; Director of Land Department of Ministry of Physical Infrastructure in Unity State; Pariang County Commissioner, February-March 2013; Aeberli, op. cit.

${ }^{55}$ Local Government Act, op. cit., Appendix II Schedule I.

${ }^{56} \mathrm{~A}$ few international aid workers, for example, reported that they interacted with county commissioners in order to ensure the success of their projects as they considered them to represent local communities. One of them was even surprised by the fact that despite the county commissioner declared its support to the project and even offered the use of his car as a contribution, the local community where the project was to be implemented totally opposed it in such a harsh way that it could not be realized. Personal communications, March and April 2013.

${ }^{57}$ Local taxes include: local rates, land tax, health card tax, permit rate, licenses, court fees, fines/penalties, slaughter fees, gibana (personal tax, which is expected to be 0 in 2013), animal taxes, royalty from sale of timbers, auction fees, bar \& restaurants, fresh \& dry fish, liquor fees, weekly collection rate, commodity taxes. Local Government Board (2012): Strategic Plan 2012-2015, Rubkhona County - Unity State.

${ }^{58}$ Local Government Act, op. cit., Section 73.

${ }^{59}$ Interviews with Director of Planning and Budgeting, Ministry of Local Government, Unity State, February 2013; Project officer, Winrock-BRIDGE program, Bentiu, March 2013.

${ }^{60}$ Schomerus, Mareike and Allen, Tim (2010): Southern Sudan at Odds with Itself: Dynamics of Conflict and Predictaments of Peace, London, Development Studies Institute- London School of Economics; Aeberli, op. cit. ${ }^{61}$ Ibid.
} 
commissioners, i.e. state governors. Some of my interviewees stated that, due to its role in managing local revenues and making relevant decision at the local level, commissionership is a very prestigious position, and go as far as claiming that a County Commissioner is currently more powerful than a state minister. As evidence for this claim, I was given a few examples of influent politicians or ex-military commanders that were moved to Commissioner positions as a form of reward, in order to improve their position, and of former Commissioners that were removed and relocated in "useless" positions because "they don't satisfy the needs of the governor". Unfortunately, I was not able to access any State budget to check the amount of financial resources destined to each state ministry; therefore I do not have clear evidence to confirm my interviewees' positions. Nevertheless, a few elements could suggest that this statement is not too far from reality. First of all, ministries do not have access to additional resources than those provided by state governments through national budget allocation and tax collection at state level, which is however weak just as at County level. A study by the Sudd Institute in 2012 found states accounted on average only for the $16 \%$ of the total GoSS spending, and only for the $12 \%$ of approved budget in the period 2006-2011. ${ }^{62}$ Finally, when it comes to external development funding, ministries do have a key coordination role but do not directly access and channel resources, as it seems counties will be increasingly empowered to do.

This idea of the relevance of the county level in order to access resources for the local level is strengthen by two recent laws regulating the management of two of the most important natural resources of the country: land and oil.

The Land Act (2009), which regulates the access and management of the land in South Sudan, is based upon the famous Garang's aphorism "the land belongs to the people". The exact meaning of this statement has long been discussed: what the Act recognizes is a form of communal right over rural land in stating that "All the land in Southern Sudan is owned by the people of Southern Sudan (...)" 63 without however specifying who is to represent the communities' interests vis-à-vis the government and especially foreign investors. According to the Local Government Act, people should rule themselves through a traditional community authority ${ }^{64}$ whose power is however limited to the judicial sphere in levels higher than the Boma. Being unclear who has the legitimacy of representing community interests, its interpretation in practical circumstances is being in pro-government way, identifying the community with the County authorities. A senior official of the Ministry of Agriculture in Unity State declared in an interview: "The land belongs to the community means that the nine counties belong to nine different clans of Nuer (...) [but] The owners of the land are the county authorities". 65

The Petroleum Act 2012 states that "The Government shall allocate and pay to the states and communities in accordance with applicable law". ${ }^{66}$ The applicable law here mentioned was formulated in 2012 but not yet approved: the draft Petroleum Revenue Management Bill attributes to States and Local Government Councils 2\% and 3\% of the Net Petroleum Revenues respectively. ${ }^{67}$ The Interpretation section of the Bill defines the Local

\footnotetext{
${ }^{62}$ Ting Mayai, Augustino: "Mapping Social Accountability: An Appraisal of Policy Influence on Service Delivery in South Sudan, 2006-2011", Policy Brief, no 1(November 2012), The Sudd Institute.

${ }^{63}$ Government of Southern Sudan (2009): Land Act, 2009, Ch. II, art. 7.1.

${ }^{64}$ Government of Southern Sudan (2009): Local Government Act, op. cit., section 114.

${ }^{65}$ Interviewed in Bentiu, March 2013.

${ }^{66}$ Government of the Republic of South Sudan: Petroleum Act, 2012, Ch. XVI, art. 74

${ }^{67}$ Government of the Republic of South Sudan Petroleum Revenue Management Bill - Draft, 2012, Ch. VII, art. 28.1 (a) (b)
} 
Government Council as: "community government that exists at the levels of government closest to the people in the states as provided for under Article 47(c) of the Constitution and established in accordance with the provisions of the Local Government Act, 2009". Being the level of government closest to the people, Counties are therefore considered as entitled to manage oil revenues on behalf of the communities, though the debate on which County institution should be in charge - the Council or the County Development Committee - is still ongoing. In 2013, some changes have been introduced in the draft bill, distinguishing between immediate communities, neighboring communities and all other communities, entitled to $45 \%, 30 \%$ and $20 \%$ of the $3 \%$ Local Government Council oil revenues respectively. This introduces another element of potential inequality among different communities, self-defined in tribal terms and bound to a particular territory whose border definition will have an outstanding importance in entitling its members to oil revenues. ${ }^{68}$ "How do you address the local people? Who are their legitimate representatives? (...)If it is not clear what we mean with community, this can cause problems over boundaries", warns a Juba University lecturer during an interview on the distribution of oil revenues. ${ }^{69}$

\section{Unity State Case-Study}

Unity State is a relatively homogeneous area in terms of ethnic composition, being mainly inhabited by Nuer sub-sections with Dinka minorities in Pariang, Abiemnom and the northern part of Rubkhona counties. Nonetheless, the area has experienced an incredibly high rate of inter-communal fighting during the war not only on the Dinka-Nuer fault line manipulated by SPLA mainstream and Nasir faction, but also in the form of intra-Nuer sub-section and clan fighting. SPLA control in the area has been historically challenged by a number of other rebel groups and militia, and even today's tensions between different SPLM factions at national level are locally very visible. ${ }^{70}$

Together with this history of internal fighting, the region is also very rich in natural resources, both land, with the toic representing only one of the pasture areas over which different communities compete, and oil.

For these reasons, Unity State is an interesting case-study to look at to assess the local effects of the delimitation of territorial unities while decentralizing the government of South Sudan.

\subsection{A Historical Background}

Unity State, once known as Western Upper Nile (WUN), is situated in the north-central part of South Sudan, with a surface of approximately 36.000 square $\mathrm{km}$. The oil discoveries in the area in the late ' 70 deeply affected the local population that was deliberately targeted and forced to flee by government proxy militias.

Since the beginning of the ' 80 s, a mostly Nuer rebel movement called Anyanya II was active in the area and its attacks against Chevron facilities and personnel caused the company

\footnotetext{
${ }^{68}$ Akec John A. and Schenkel Kathelijne: "Petroleum revenues distribution to local communities in South Sudan", Sudan Tribune (5 June 2013).

${ }^{69}$ Interview in Juba, 17 January 2013.

70 The latest example is the removal of Unity State governor Taban Deng Gai in July 2013. Sudan Tribune: “South Sudan's Kiir relieves Unity State governor Taban Deng”, 7 July 2013.
} 
shut-down of activities. Only after having absorbed part of Anyanya II, between 1984 and 1986, was the SPLA able to enter the area and put under its control most of WUN territory, except for some garrison towns and oilfields in the north. By the end of the '80s, the bulk of Anyanya II joined the rebel movement, except for Bul Nuer forces of Paulino Matiep that remained active in Mayom and Mankien and allied with Khartoum. After a short period of unity, new militias opposing the rebel movement started to operate. In 1991 Riek Machar Teny, former SPLA Zonal Commander in Western Upper Nile, Gordon Kong (a Nuer from Nasir) and Lam Akol (a Shilluk from Upper Nile) broke away from SPLA after an attempted coup against its leader John Garang. The split, which led to the creation of the SPLM-Nasir faction, caused huge losses to the SPLA in terms of soldiers and control of the territory, with major oilfields under SPLM-Nasir (later on SPLM-United and South Sudan Independent Movement).

For almost a decade, Western Upper Nile was under the control of splinter groups, which alternatively allied with the government, fighting each other and the SPLA. ${ }^{71}$ Ethnicity was widely manipulated during the 90s, affecting not only Dinka-Nuer relations (Garang versus Riek Machar) but also intra-Nuer relations. ${ }^{72}$

Bentiu remained under direct control of the Sudanese army as other garrison towns in Southern Sudan, while most of the rural areas were under Riek Machar's forces or other militias' control, that were virtually neutralized with the signing of the Khartoum Peace Agreement (1997). Before entering the peace agreement, Paulino Matiep's Bul Nuer militia was used by the government to secure the oilfields in the western part of Western Upper Nile. He was then integrated in the Sudanese Army as a Major General, and his movement was renamed South Sudan Unity Movement/Army. He continued to be active in Mayom area. ${ }^{73}$ Baggara militias, which seasonally migrated to southern Dinka and Nuer lands in search for water and pastures, were also armed and used to displace people.

The control of the area between 1991 and 2002 was contended between Paulino Matiep's militia and Riek Machar's faction, with the current governor Taban Deng Gai as a key figure in the area and a number of splinter micro-groups allying alternatively with rebel factions or the Khartoum government. ${ }^{74}$ By the end of the 90 s, SSDF in Western Upper Nile, headed by Tito Biel, started to realign with the SPLM/A, but the rebel movement's physical presence in the area was only re-established after Peter Gadet's defection to SPLM/A in $2000 .^{75}$

In 2002, the South Sudan Defense Forces (SSDF), created by the Khartoum Peace Agreement and led by Riek Machar, rejoined the SPLA after negotiations held in Nairobi between the SPLM/A headquarter and Taban Deng Gai on behalf of SSDF. The latter was appointed Unity State governor after the signing of the Comprehensive Peace Agreement in 2005 and was confirmed in the position by 2010 highly contested election.

\footnotetext{
${ }^{71}$ Johnson D. H.: The root causes..., op. cit.; Human Rights Watch (2003): Sudan, Oil and Human Rights, New York, HRW, available at http://www.hrw.org/reports/2003/sudan1103/sudanprint.pdf.

${ }^{72}$ Johnson D. H.: The root causes..., op. cit.; Hutchinson: "A curse from God?...", op. cit.; Human Rights Watch, op. cit.; African Rights, op. cit.

${ }^{73}$ Human Rights Watch, op. cit.

${ }^{74}$ Ibid.

${ }^{75}$ Peter Gadet was formerly Zonal Commander in Paulino Matiep's South Sudan Unity Movement/Army. His munity caused the loss of most of SSUM/A Bul and Leek Nuer troops in Mankien. Ibid.
} 


\subsection{Disputed Internal Borders}

As shown above, Unity State has a history of internal cleavages whose expression in tribal terms has been exacerbated by the widespread manipulation of ethnicity as a means of mobilization during the war by all parties to the conflict.

Its borders, as those of all the other South Sudanese states, are inherited by previous regimes, with the colonial period being considered as a landmark. ${ }^{76}$ Conflicts with neighbouring states (mainly Lakes and Warrap) for reasons including artificial colonial demarcation, access to grazing land and water sources are most common during the dry season when movements are easier and people are in need of water for themselves and their cattle. These conflicts, often expressed in terms of cattle-raiding, are usually violent and deadly both for humans and cattle and receive most of the attention from the media and public opinion. Efforts to solve them involve state authorities and local chiefs, but are not necessarily articulated as border issues. This might be because the state is still looked as a far away level of government, having little to do with actual control, management and problem-solving of local daily life.

Less attention is given to internal border conflicts between Unity State counties. A report published by the South Sudan Bureau for Community Security and Small Arms Control, the South Sudan Peace and Reconciliation Commission and the UNDP in 2012 assessing the typologies and causes of conflicts in Unity State counties, found that border conflict was identified as a major problem by most of the counties surveyed. Although the areas most affected by Misseriya migrations (Abiemnom and Pariang) only mentioned the international border issue, all the others recognized internal border as one of the conflict issues, together with access to grazing land and water, food insecurity, small arms, etc. Two of them, Rubkhona and Guit, even put it as the highest priority to be addressed. ${ }^{77}$

Unity State current division into Counties was made when the area went back under SPLA control. ${ }^{78}$ Rubkhona and Mayom were created in 1999-2000 when Peter Gadet joined the SPLA. In 2002, when also Riek Machar was reabsorbed in the SPLA, Mayendit, Leer and Pariang were created. Panyinjiar, Guit and Abiemnom were created in 2005 after the signing of the peace agreement. ${ }^{79}$ Unlike other states in South Sudan, ${ }^{80}$ no new counties were created after 2005 despite some few requests ${ }^{81}$ that were however repulsed, perhaps because the number of Counties is already the same as the number of Nuer and Dinka tribes considered to traditionally inhabit the area. On the other hand, the number of Payams proliferated. For example, Rubkhona County Commissioner reports the creation of 6 new Payams in his county in the last year only:

"We have 6 new Payams. The old ones used to be on the northern side of the river, while those new ones are on the southern side because we need to bring development also

\footnotetext{
${ }^{76}$ Interview to senior official of Local Government Board, Juba January 2013; Schomerus and Allen, op. cit.

${ }^{77}$ UNDP: "Community Consultation Report - Unity State - South Sudan", Bureau for Community Security and Small Arms Control, South Sudan Peace and Reconciliation Commission, (May 2012), Juba.

${ }^{78}$ Interview with Member of Parliament from Mayom Country in Unity State Legislative Assembly, Bentiu, February 2013.

${ }^{79}$ Ibid.; UNDP: "Community Consultation Report...” op. cit.

${ }^{80}$ Schomerus and Allen, op. cit.

${ }^{81}$ Interview with Member of Parliament from Rubkhona County in Unity State Legislative Assembly, Bentiu, February 2013.
} 
there ${ }^{82}$. Dhorbor split in Kuerkuei, Budaang changed its name in Badaang and split into another one that still has no name, Ngop split into Thorbon, and two new ones are Chor and Tomodol. Every time a new Payam is formed, a new head chief is elected". ${ }^{83}$

During my two month field research, I tried to identify some of the border disputes involving the northern Counties of Unity State, particularly Rubkhona, Guit, Pariang and Mayom, highlighting their immediate cause and the interests at stake in each case. The findings are summarized in the table below. ${ }^{84}$

\begin{tabular}{|c|c|c|c|c|}
\hline $\begin{array}{l}\text { Disputed } \\
\text { area }\end{array}$ & $\begin{array}{l}\text { Counties } \\
\text { involved }\end{array}$ & Dispute details & Interest & Resolution \\
\hline Wangkei & $\begin{array}{l}\text { Rubkhona - } \\
\text { Mayom }\end{array}$ & $\begin{array}{l}\text { Wangkei Payam is part of Mayom } \\
\text { County, but it is on the very border } \\
\text { with Rubkhona. In } 2010 \text { people } \\
\text { from Wangkei wanted to build } \\
\text { houses in an area that was claimed } \\
\text { by Rubkhona. There were clashes } \\
\text { and a head chief from Mayom was } \\
\text { killed. In } 2012 \text { there was fighting } \\
\text { again and cattle-raiding. }\end{array}$ & $\begin{array}{l}\text { Tax collection } \\
\text { Land ownership }\end{array}$ & $\begin{array}{l}\text { The security was } \\
\text { sent and houses } \\
\text { removed. No } \\
\text { permanent } \\
\text { agreement found. } \\
\text { Waiting for official } \\
\text { demarcation. }\end{array}$ \\
\hline Port (Mina) & $\begin{array}{l}\text { Rubkhona - } \\
\text { Guit }\end{array}$ & $\begin{array}{l}\text { The port is on the river Nam (Bahr } \\
\text { el Ghazal), next to the bridge } \\
\text { linking Bentiu to Rubkhona. Since } \\
2011-12 \text { there is also a small } \\
\text { market. Goods arrive there by boat } \\
\text { from Malakal (especially during } \\
\text { the rainy season), and by road } \\
\text { from Mayom. The place is called } \\
\text { Mina, it used to be in Rubkhona } \\
\text { County but Guit authorities are } \\
\text { now collecting taxes both on } \\
\text { goods coming through the river } \\
\text { and from the traders. } \\
\text { Allegedly, Rubkhona community } \\
\text { claims the land because of a Leek } \\
\text { man having planted some mango } \\
\text { trees in the area. }\end{array}$ & $\begin{array}{l}\text { Tax collection on } \\
\text { goods and } \\
\text { market fees } \\
\text { Land }\end{array}$ & $\begin{array}{l}\text { No explicit claims } \\
\text { from Rubkhona } \\
\text { people, but they are } \\
\text { unhappy with this } \\
\text { arrangement }{ }^{85} \text {. } \\
\text { No effort to solve } \\
\text { the issue by the } \\
\text { government. } \\
\text { Waiting for official } \\
\text { border demarcation. }\end{array}$ \\
\hline $\begin{array}{l}\text { Parts of } \\
\text { Bentiu } \\
\text { (Power } \\
\text { station-Bim } \\
\text { Ruo/Yoanya } \\
\text { ng) }\end{array}$ & $\begin{array}{l}\text { Rubkhona - } \\
\text { Guit }\end{array}$ & $\begin{array}{l}\text { Bim Ruo/Yoanyang is an area } \\
\text { north-east of Bentiu where the } \\
\text { town is expanding, and it borders } \\
\text { Guit County. The area is inhabited } \\
\text { by a sub-clan of Leek } \\
\text { (Rubkhona), Chiengain, and a sub- } \\
\text { clan of Jikani (Guit), Chiengdukar. }\end{array}$ & Tax collection & $\begin{array}{l}\text { Security } \\
\text { intervention. No } \\
\text { agreement reached. }\end{array}$ \\
\hline
\end{tabular}

\footnotetext{
${ }^{82}$ After oil discoveries on the northern side of the river, most of the population previously living there was forcefully displaced to the southern part by militias. Human Rights Watch, op. cit.

${ }^{83}$ Interview with Rubkhona County Commissioner, Rubkhona, February 2013.

${ }^{84}$ Sources of information were primarily interviews with members of Unity State Legislative Assembly from Rubkhona, Pariang, Guit and Mayom Counties, Rubkhona and Pariang County Commissioners, Nyeel Payam acting Administrator, Unity State Land Commission chairperson and members of Unity State civil society based in Bentiu Town.

${ }^{85}$ General views from average citizens were collected through informal talks in the areas of Iengas and Bim Ruo, which are close to the port area and, at times, are also claimed by Guit County. Bentiu Town, in March 2013. Some interviewees suggested that claims are not publicly raised when they involve complaining against the expansionist attitude of Guit County because it is the governor's home county.
} 


\begin{tabular}{|c|c|c|c|c|}
\hline & & $\begin{array}{l}\text { Before Guit was created in } 2005 \text {, } \\
\text { they lived together. Between } 2002 \\
\text { an } 2007 \text { the area was under the } \\
\text { control of a militia led by Peter } \\
\text { Dor of Chiengdukar clan, that was } \\
\text { then integrated in the SPLA }{ }^{86} \text {. In } \\
2002 \text {, a market was established. In } \\
2007 \text {, there was a dispute among } \\
\text { tax collectors that escalated into } \\
\text { fighting between the communities } \\
\text { in Maderasa and Chilak, along the } \\
\text { river. } \\
\text { In march } 2008 \text { there were new } \\
\text { clashes between the two } \\
\text { communities. The government } \\
\text { intervened destroying the market } \\
\text { and residential area. People are } \\
\text { now residing there illegally. It is a } \\
\text { barrack area. }\end{array}$ & & \\
\hline Heglig & $\begin{array}{l}\text { Rubkhona - } \\
\text { Pariang }\end{array}$ & $\begin{array}{l}\text { Leek people (from Rubkhona) } \\
\text { claim part of Heglig because they } \\
\text { used to go to graze in the area and } \\
\text { consider it to be their land. }\end{array}$ & $\begin{array}{l}\text { Tax collection } \\
\text { Oil revenues } \\
\text { Land ownership }\end{array}$ & $\begin{array}{l}\text { Heglig is stil } \\
\text { disputed between } \\
\text { Sudan and South } \\
\text { Sudan }\end{array}$ \\
\hline Manga & $\begin{array}{l}\text { Pariang - } \\
\text { Guit }\end{array}$ & $\begin{array}{l}\text { Manga is situated east of } \\
\text { Rubkhona, near to the river Nam. } \\
\text { It is claimed by Pariang County } \\
\text { (Dinka Rweng-Panaru), but is } \\
\text { where the house of Unity State } \\
\text { Governor Taban Deng Gai is } \\
\text { located. The governor allegedly } \\
\text { encouraged the settlement of Nuer } \\
\text { Jikani (his own tribe) in the area, } \\
\text { which is now under the authority } \\
\text { of Guit County (before, it was part } \\
\text { of Nyeel Payam in Pariang } \\
\text { County). Dinka Panaru claim that } \\
\text { the traditional border used to be } \\
\text { the river Nam, with Nuer Jikani } \\
\text { living south. The original name of } \\
\text { the area was Minyang while } \\
\text { Manga would the arab name, } \\
\text { allegedly used by the governor to } \\
\text { hide the origins of the place. } \\
\text { Before the war, it used to be a } \\
\text { grazing area (not heavily } \\
\text { populated) and the few inhabitants } \\
\text { were displaced following inter- } \\
\text { tribal militia fighting in 1991- } \\
\text { 1992. }\end{array}$ & $\begin{array}{l}\text { Agriculture land } \\
\text { Water } \\
\text { Fish camp }\end{array}$ & $\begin{array}{l}\text { People from } \\
\text { Pariang are } \\
\text { unhappy with the } \\
\text { arrangement, but } \\
\text { there are no } \\
\text { protests. People are } \\
\text { either waiting for } \\
\text { official } \\
\text { demarcation, either } \\
\text { too scared to } \\
\text { protest against the } \\
\text { governor. }\end{array}$ \\
\hline
\end{tabular}

\footnotetext{
${ }^{86}$ According to a Member of Parliament from Guit County in Unity State Legislative Assembly, it was only after 2007 that the government of Unity State was effectively capable of controlling the area between Rubkhona and Guit. Interviewed in Bentiu, February 2013. A Block leader in Bentiu Town I interviewed in March 2013 also reported the presence of armed groups in Rubkhona until 2007: "Arabs stayed in Rubkhona up to 2007".
} 
All these disputes are conceptualized both in terms of tribal and clan-based affiliation and in terms of where a particular border has to lay; the issues at stake -besides the symbolic rhetoric of "this is our ancestral land"- are mainly reported to be access to land and tax collection.

The first one, access to land, can be approached from two distinct but intertwined perspectives: access to land on an individual basis, and access to land on a collective (community) basis. Individual access to land in the rural areas is granted on customary basis. Except from Bentiu Town and a few other towns where the demarcation of urban housing plots is under way, ${ }^{87}$ Unity State's population mostly lives in the rural areas, where land is allocated to the people according to the needs for settlement and productive land by the local chief. The allocation of land takes place at Payam level (Head chieftainship) through the consultation of Boma level chiefs (Executive chieftainship) that identify the plots to be allocated. This practice is consistent both with the Land Act, which recognizes customary rights to land in the rural areas, and with the way in which local land issues have been traditionally dealt with. Customary rights, as such, have been traditionally regulated by local chiefs with very limited interference from any form of statutory power. ${ }^{88}$ In their study of local administration in SPLA controlled areas during the war, Branch and Mampilly report that land disputes' resolution between individuals and families were to be managed within the customary system, with a council of chiefs and elders as appeal organ instead of the SPLM statutory court. ${ }^{89}$ Individual land rights are therefore mediated by the right of an entire community to own, access and occupy a certain territory, with the community "defined as a tribal unit, in which decisions as to the most important resource, land, are made exclusively by those seen as embodying that tribal custom - chiefs and elders". ${ }^{90}$ According to a senior official of the Ministry of Agriculture in Unity State:

\begin{abstract}
"If you want a plot for farming, there are no problems and it is free as long as you belong to that community. Otherwise you will never have it, forget it! You can ask for a lease, but then you have to pay". ${ }^{1}$
\end{abstract}

Having to pay for the land to live and cultivate means virtually being excluded from that land for the majority of people living in the rural areas, so if an area is included or not in the administrative boundaries that delimit a community's territory becomes a matter of being allowed or denied the right to access that land to individual community members. Moreover, while for urban land an official survey system and fixed prices are in place -notwithstanding reports of widespread corruption of local officers of the Survey Department-, it is unclear how the issue is supposed to work in the rural areas.

\footnotetext{
${ }^{87}$ The Director of the Land Department of the Ministry of Physical Infrastructure and Urban Development in Unity State reported in an interview that between 2004 and 2011 the following urban blocks for housing were demarcated: 1 block in Pariang town; 6 blocks in Guit Town, 9 blocks in Abiemnom town; 3 blocks in Mankien; 7 blocks in Wankai; 9 blocks in Mayom Town; 12 blocks in Rubkhona town; 97 blocks in Bentiu (but rapidly expanding). Interviewed in Bentiu, February 2013.

${ }^{88}$ I am not considering here the large scale expropriation of land in the Upper Nile region by the government in Khartoum during the 70s and 80s (Johnson D.H.: "The root causes...", op. cit), because this kind of operation should be looked at as an alienation of collective rights involving logics and dynamics that go far beyond the negotiation of customary rights.

${ }^{89}$ Branch and Mampilly, op. cit.

${ }^{90}$ Ibid., p. 11.

${ }^{91}$ Interviewed in Bentiu, February 2013.
} 
This individual perspective would not be enough, however, to understand why disputes arise and articulate on county borders: the same issue of individual access to land could, and indeed does, emerge also at Payam and Boma levels on clan and sub-clan bases, ${ }^{92}$ though the chairman of the Land Committee in Unity State Legislative Assembly suggests that these disputes are usually solved more easily by Head Chiefs and Executive chiefs. ${ }^{93}$

Access to land on a collective basis entails a broader perspective of what it means in terms of access to resources, that goes beyond subsistence usage. As shown above, Local Government Councils (i.e. Counties), are increasingly identified as key actors in any development activity, which include, among other things, also benefiting from the revenues deriving from natural resources exploitation. Though not yet implemented, provisions contained in the legislation have the potential of making natural resources -including land- an important source of income for local governments.

The second issue mentioned, tax collection, represents both a source of income that can be seen in a similar way, and a powerful symbolic act. From tax collectors' point of view, tax collection has the symbolic meaning of being capable to control a territory. From the point of view of those that pay taxes, it means that they "belong" to a certain group or community, and in this way show their participation and allegiance to a polity. When asked to which county the port and market on the river Nam belonged, the traders replied that it belonged to Guit County, because it was Guit authorities that collected taxes from them. ${ }^{94}$ People do not want to be taxed by authorities that they perceive as alien: for example, in the case of Bim Ruo/Yoanyang, the dispute reportedly started as a quarrel between tax collectors and later escalated into inter-clan fighting between Jikany and Leek clans because the people did not want to demonstrate allegiance to the other's County authorities, even if before 2005 the people were living together because Guit County did not exist. ${ }^{95}$

The availability of revenues (from tax collection, natural resources exploitation or simply government or donor grants) is associated with service delivery and development opportunities, the lack of which is seen not as a "failure of [institutional] accountability but rather a failure of political representation and access to political power". ${ }^{96}$ Social services and development opportunities, epitomized by Garang's statement "Taking towns to the people", are widely believed to be delivered based on tribal affiliation, as it is exemplified by the dispute between Leek and Jikani Nuer to control parts of Bentiu town. "The proximity of the county capital is seen to be accompanied by improved disbursement of funds for basic services. Access to affordable food and available medical services and schools are seen to be a product of having the 'government' nearby", 97 and this "nearby government" is supposed to be the "community government".

Communities are identified and identify themselves in tribal and clanic terms, and this is most evident in the effort of turning "traditional" customary boundaries into "modern"

\footnotetext{
92 Schomerus and Allen, op. cit.; Interviews with Member of Parliament from Guit County, Unity State Legislative Assembly, Bentiu, February 2013, Unity State Land Commission chairman, Bentiu, March 2013.

${ }^{93}$ Interviewed in Bentiu, March 2013.

${ }^{94}$ Informal talks with traders in the Mina port and market area on the river Nam, March 2013.

${ }^{95}$ Interview with Member of Parliament from Guit County, Unity State Legislative Assembly, Bentiu, February 2013. Rubkhona and Guit County are considered to belong respectively to the Leek Nuer sub-tribe and to Jikany Nuer sub-tribe. The dispute arose as soon as both counties authorities started to try to collect taxes, in 2007, as between 2005 and 2007 the area was still partly controlled by an armed militia.

${ }^{96}$ Schomerus and Allen, op. cit. p.42.

${ }^{97}$ Ibid. The control over Bentiu town also entails higher revenues in terms of commodity tax collection, as the capital town is where major markets are located.
} 
administrative borders. The overlapping of the particularistic sphere of the community and the universalistic one of the local government in charge of development and service delivery, is somehow endorsed by the Local Government Act that recognizes the "traditional community authority" as expression of the people's self-rule ${ }^{98}$ implying therefore a stronger role for the chiefs without however mentioning specific mechanisms to entrench their downward accountability nor possible safeguard mechanisms for "aliens" to a particular community. The call for self-rule constitutes the other outstanding element of the Government of South Sudan's commitment to decentralization. If the two things, self-rule and service delivery, are to go together in a decentralized system, it seems that the persistent perception of access to resources being granted along tribal lines while officializing them into administrative borders is more likely to cause localized conflicts than to solve them, especially in a context such as Unity State -and the broader South Sudan- where ethnicity has already been extensively exploited for political reasons along its whole history.

\section{Conclusions}

This paper has shown how the creation of a decentralized system of government in a context of post-conflict state-building needs necessarily to cope with the challenges stemming from the delimitation of territorial units that will form the base for local government empowerment. The idea, popular among international agencies contributing to South Sudan state-building effort, that a decentralized government would best meet the goals of peace-building seems sometimes to overlook the fact that, although beneficial for managing tensions at a national level allowing broader political inclusion through the creation of a number of new local political arena, it can sometimes have contrasting impacts on the local level.

Though the majority of my interviewees supported the idea that a decentralized system is the best way to govern South Sudan respecting its people's right to self-rule, this paper has raised some critical aspects on the local impact of the creation of decentralized governmental structures, starting from local borders. According to Schomerus and Allen, "Decentralization, while theoretically the best way to govern Southern Sudan, has in reality become an instrument to entrench 'tribal' lines over competition for resources, manifesting itself in a proliferation of new counties". 99

In particular, Unity State case-study showed that institutionalization of county borders is going hand in hand with an increase in localized disputes over resources. These disputes have to do with the overlapping of the "traditional" customary domain with the "modern" administrative local government unit, creating tensions between a particularistic, identitybased idea of self-rule, and universalistic statehood supposed to protect the rights to resources access of all its citizens. This tension is likely to increase the more the local government will be empowered to carry out its tasks with increased access to natural resources revenues. So far, violent clashes have occurred only occasionally, but if the issue is not addressed and continues to be postponed to when all major troubles with Sudan and the international border will be solved, its capacity of deteriorating local relations between communities and hindering state-building at a local level (represented by state institutions that do not deliver what are expected to) should be taken into account.

\footnotetext{
${ }^{98}$ Local Government Act, op. cit, art. 114.

${ }^{99}$ Schomerus and Allen, op. cit., p. 9
} 